\title{
Growth Parameters and Herbage Yield of Java Citronella as Influenced by Nutrient Management under Inceptisol
}

\author{
S.P. Nandapure ${ }^{1 *}$, S.G. Wankhade ${ }^{2}$, S.R. Imade ${ }^{3}$, R.V. Mahajan ${ }^{3}$ and G.S. Doiphode ${ }^{4}$ \\ Department of Soil Science and Agricultural Chemistry, Dr. Panjabrao Deshmukh Krishi \\ Vidyapeeth, Akola - 444 104, Maharashtra, India \\ ${ }^{1}$ Agricultural Prices and Costs Scheme, Dr. PDKV, Akola (M.S.), India \\ ${ }^{2}$ Department of Soil Science and Agricultural Chemistry, Dr. PDKV, Akola (M.S.), India \\ ${ }^{3}$ Agronomy, Anand Niketan College of Agriculture, Warora (M.S.), India \\ ${ }^{4}$ Agricultural Technical School, Warud, Tq. Pusad, Dist. Yavatmal (M.S.), India \\ *Corresponding author
}

\section{A B S T R A C T}

\section{Ke y w o r d s \\ Java citronella, Nutrient management, Plant height, Number of tillers, Herbage yield}

\section{Article Info}

\section{Accepted:}

15 April 2020

Available Online:

10 May 2020
The field study was carried out during kharif 2009-10 and 2010-11. The fertility status of the soil was moderate in organic carbon, low in available $\mathrm{N}$ and $\mathrm{P}$ and very high in available $\mathrm{K}$ while the soil micronutrient contents $(\mathrm{Zn}, \mathrm{Fe}, \mathrm{Mn}, \mathrm{Cu}$ ) were above the critical level. Experiment comprised of thirteen treatments replicated thrice in randomized block design, involving control (no fertilizer/manure), 5 t FYM ha ${ }^{-1}, 10 \mathrm{t} \mathrm{FYM} \mathrm{ha}^{-1}, 80: 20: 40 \mathrm{~kg}$ NPK ha ${ }^{-1}, 100: 30: 60 \mathrm{~kg}$ NPK $\mathrm{ha}^{-1}, 140: 40: 80 \mathrm{~kg} \mathrm{NPK} \mathrm{ha}^{-1}, 5$ t FYM + 80:20:40 kg NPK $\mathrm{ha}^{-1}, 5$ t FYM + 100:30:60 kg NPK ha ${ }^{-1}, 5$ t FYM + 140:40:80 kg NPK ha ${ }^{-1}, 10$ t FYM + 80:20:40 kg NPK ha ${ }^{-1}, 10$ t FYM + 100:30:60 kg NPK ha-1, 10 t FYM + 140:40:80 kg NPK ha ${ }^{-1}$ and $100 \mathrm{~kg} \mathrm{~N}$ through FYM (based on FYM analysis). The results from the experimentation indicated that, the combined application of FYM + NPK @ $10 \mathrm{t}+$ 140:40:80 kg ha ${ }^{-1}$ resulted in maximum plant height $(140.20 \mathrm{~cm})$ and number of tillers (58.43) followed by $5 \mathrm{t} \mathrm{FYM} \mathrm{+140:40:80} \mathrm{kg} \mathrm{NPK} \mathrm{ha}{ }^{-1}$ which was significantly superior over rest of the treatments. Herbage yield was comparatively higher during the second year of the crop and it was increased successively with each combination of increasing FYM levels and graded doses of NPK. Significantly highest herbage yield was recorded with 10 t FYM along with 140:40:80 $\mathrm{kg} \mathrm{NPK} \mathrm{ha}^{-1}$. From the results, it can be concluded that the conjunctive use of FYM along with chemical fertilizer (10 t FYM + 140:40:80 kg NPK ha ${ }^{1}$ ) was found beneficial way of nutrient management to increase the plant height, number of tillers and herbage yield of Java citronella.

\section{Introduction}

In India and particularly in Maharashtra the dry land agriculture has prime role in food crop production. However, the undependable and erratic rainfall in the region introduces an element of risk, uncertainty and instability in crop production, which resulting into financial deterioration of rural farming sector. Farming community is in search of non- 
traditional cropping systems, suitable for dryland agriculture, indicating the diversification in agriculture, however, the selection of the crop for diversification should be based on their adaptability and economic returns. Changing the pattern of commercial crops has become an ecological need however, it is necessary that the introduction of new crops should be economically viable in a particular region.

Cymbopogon winterianus commonly known as Java citronella belongs to Graminae family and is originally from Sri Lanka was selected for the study. It is a tall perennial tufted aromatic grass with superficial fibrous roots. It is basically, a tropical plant mainly cultivated in Indonesia, Sri Lanka, China and India. In India, major producing area is the tea gardens in Assam and to a limited extent in states like U.P., Maharashtra, Karnataka, Gujarat, Manipur, Meghalaya, Tamil Nadu, Nagaland, Uttaranchal, A.P. and Tripura where it is commercially cultivated and distilled for its oil (Shiva et al., 2002).

The oil is used mostly in perfumery, both directly and indirectly in soaps, soap flakes, cosmetics, detergents, agarbatties, insecticides, etc. are often perfumed exclusively with this oil. Small quantity of citronellal is used in perfumery as an aromatic chemical. However, the greatest importance of citronellal lies in its role as a starting material for further derivatives. It is good mosquito repellant. The leftover of the citronella grass has been recommended to be utilized as source of raw material for cellulose pulp and paper production by using sulphate, sulphite and cold caustic soda.

Java citronella accumulates the biomass and nutrients very rapidly only after five months of planting and the biomass production and nutrient uptake was found to be highest after ten months of plant growth. The concentrations of $\mathrm{N}, \mathrm{P}$ and $\mathrm{K}$ did not fluctuate much throughout year (Prakasa Rao and Ganesha Rao, 1986).

At present no information is available on nutrient management of these grasses under agroclimatic condition of Vidarbha region of Maharashtra. Being a perennial crop periodic replenishment of nutrients is essential to keep the plantation viable for 4-5 years. Therefore, keeping in view of above facts the present investigation was carried out.

\section{Materials and Methods}

\section{Study site and treatment details}

The field experiment was conducted during Kharif seasons of 2009-10 and 2010-11 at Nagarjun Medicinal Plants Garden, Dr. PDKV, Akola (latitude of $22^{0} 41^{\prime} \mathrm{N}$ and longitude of $77^{0} 02^{\prime} \mathrm{E}$ with an altitude 307.41 meters). The climate of experimental site is semi-arid and subtropical with extreme conditions having hot and dry summer and cold winter, where maximum temperature goes up to $42.6^{\circ} \mathrm{C}$ during summer and minimum as low as $10.3^{\circ} \mathrm{C}$ during winter. The annual average rainfall of area is $764.7 \mathrm{~mm}$. The soil of the experimental field was medium black, Smectitic, clay loam in texture and classified as Typic Haplustept which comes under the soil order Inceptisol. The initial soil analysis indicated that, the soil was calcareous in nature and moderately alkaline in reaction. In case of physical properties the soil was low in hydraulic conductivity and available water capacity. The fertility status of the soil was moderate in organic carbon, low in available nitrogen and available phosphorus and very high in available potassium while the soil micronutrient contents $(\mathrm{Zn}, \mathrm{Fe}, \mathrm{Mn}, \mathrm{Cu})$ were above the critical level. The experiment was laid out with randomized block design having three replication comprising of 13 treatments, viz 
Control (no fertilizer/manure), $5 \mathrm{t}$ FYM ha ${ }^{-1}$, 10 t FYM ha ${ }^{-1}$, 80:20:40 kg NPK ha-1, 100:30:60 kg NPK ha-1, 140:40:80 kg NPK $\mathrm{ha}^{-1}, 5$ t FYM + 80:20:40 kg NPK ha-1, 5 t FYM + 100:30:60 kg NPK ha ${ }^{-1}, 5$ t FYM + 140:40:80 kg NPK ha ${ }^{-1}, 10$ t FYM + 80:20:40 kg NPK ha ${ }^{-1}, 10$ t FYM + 100:30:60 kg NPK $\mathrm{ha}^{-1}, 10 \mathrm{t}$ FYM + 140:40:80 $\mathrm{kg} \mathrm{NPK} \mathrm{ha}^{-1}$ and $100 \mathrm{~kg} \mathrm{~N}$ through FYM (based on FYM analysis). Treatment wise FYM was added on dry weight basis before planting of Java citronella during 2009-10 contain $0.67 \% \mathrm{~N}$, $0.22 \% \mathrm{P}$ and $0.49 \% \mathrm{~K}$ and in the month of April 2010 contain $0.64 \% \mathrm{~N}, 0.20 \% \mathrm{P}$ and $0.51 \% \mathrm{~K}$ after $3^{\text {rd }}$ cutting as per treatments. Treatment wise Nitrogen, Phosphorus and Potassium doses were applied in both the years (2009-10 and 2010-11). Nitrogen was applied through urea in three split doses as per treatment after each cutting. Full dose of Phosphorus and Potassium was applied as a basal dose at the time of planting through single super phosphate and muriate of potash as per the treatments.

\section{Sowing and harvesting}

The study started on $7^{\text {th }}$ July 2009 , when Java citronella 'Bio-13' plantlets were planted (rooted slips @ 16666 slips ha ${ }^{-1}$ ). A spacing of 90 x $60 \mathrm{~cm}$ was maintained between each planting. The plantlets were irrigated soon after transplantation and thereafter as and when needed during the experiment. Java citronella was harvested by cutting the leaf blade at its base, i.e., approximately $10-12 \mathrm{~cm}$ above the ground. During the two seasons of the study, the crop was harvested 6 times.

\section{Growth contributing parameters and Herbage yield}

The ten plants were selected randomly from each treatment per plot for recording yield contributing parameters. The plant height and number of tillers was recorded at every cutting and average height and average number of tillers was recorded. The fresh weight of Java citronella grass was recorded treatment wise at each cutting and computed for herbage yield per hectare by multiplying hectare factor.

\section{Statistical analysis}

Standard method of analysis known as 'Analysis of Variance' was applied for the statistical analysis. The critical difference (C.D.) was worked out at 5\% level of significance for the treatment comparison wherever the ' $F$ ' test recorded significant. Pooled analysis of two years data was carried out as per procedure described by Gomez and Gomez (1984).

\section{Results and Discussion}

\section{Plant height}

The data pertaining to plant height of Java citronella as influenced by different treatments of nutrient management during 2009-10 and 2010-11 are presented in table 1. The wide variation in plant height was noticed due to different treatment application and the plant height was in the range of 47.13 $140.65 \mathrm{~cm}$. comparatively more plant height was observed during the second year study.

\section{Effect of organic manure (FYM)}

The application of organic manure (FYM) at different doses significantly increased the plant height during both the years. It is observed that the plant height was found to increase with each dose of FYM and significantly highest plant height was recorded with the application of $10 \mathrm{t} F Y M$ $\mathrm{ha}^{-1}\left(\mathrm{~T}_{3}\right)$ as compared to control $\left(\mathrm{T}_{1}\right)$. However, it was at par with the application of 5 t FYM ha ${ }^{-1}\left(\mathrm{~T}_{2}\right)$. Similar observations have also been made by Pareek et al., (1983) and 
Anonymous (1998). Further, the data showed that the application of $100 \mathrm{~kg}$ nitrogen through FYM dose on the basis of nitrogen analysis $\left(\mathrm{T}_{13}\right)$ recorded comparatively more plant height than the plant height recorded with $10 \mathrm{t} \mathrm{FYM} \mathrm{ha}^{-1}\left(\mathrm{~T}_{3}\right)$ however it was at par with the treatment. The study by Maheshwari et al., $\left(1991^{\mathrm{a}}\right)$ also reported increased in plant height of rainfed Palmarosa with the application of FYM @ $15 \mathrm{t} \mathrm{ha}^{-1}$ as compared to control under Vertisol.

\section{Effect of NPK fertilizer}

The application of NPK fertilizer doses significantly increased the plant height as compared to alone application of FYM doses. Anonymous $\left(1987^{\mathrm{d}}\right)$ reported increased in plant height with nitrogen application than FYM alone. Further, the plant height was found to increase with each addition of NPK dose and significantly highest plant height was recorded with the application of 140:40:80 kg NPK ha ${ }^{-1}\left(\mathrm{~T}_{6}\right)$ however, the significant effect was noticed during first year and the pooled data also. Increased in plant height with the nitrogen application reported by Prakasa Rao et al., (1983), Singh and Singh (1998) and Anonymous (2012) with the phosphorus and potassium application Sukhmal Chand and Rajeswara Rao (1996), and nitrogen, phosphorus application Pareek et al., (1981 $1^{\mathrm{b}}$ ) and Wankhade et al., (2010).

\section{Combined effect}

The data presented in table 1 further revealed that the plant height was found to increased with the application of FYM doses along with graded doses of NPK fertilizer. It is also noticed that the plant height was successively increased with the application of FYM along with graded doses of NPK and significantly highest plant height was recorded with treatment $\mathrm{T}_{12}$ i.e. application of $10 \mathrm{t} \mathrm{FYM}+$ 140:40:80 kg NPK ha-1. The treatment effect was found significant during first year and in pooled means. Although, the maximum plant height was recorded with treatment $T_{12}(10 \mathrm{t}$ FYM + 140:40:80 kg NPK ha $\left.{ }^{-1}\right)$ followed by treatment $\mathrm{T}_{9}(5 \mathrm{t}$ FYM + 140:40:80 kg NPK $\left.\mathrm{ha}^{-1}\right)$, the treatment differences of combination doses were statistically at par. The results are confirmed with the findings of Maheshwari et al., (1993) and Sukhmal Chand et al., (1996).

From the pooled data (table 1) it is observed that among the treatments comprised of FYM doses, the FYM treatment equivalent to 100 $\mathrm{kg} \mathrm{N}$ ha $^{-1}$ recorded significantly maximum plant height $(77.76 \mathrm{~cm})$ as compared to $T_{2}$ (FYM @ $5 \mathrm{t} \mathrm{ha}^{-1}$ ) and $\mathrm{T}_{1}$ (control), however, it was found at par with treatment $\mathrm{T}_{3}$ (FYM @ $\left.10 \mathrm{t} \mathrm{ha}^{-1}\right)$. The data further showed that the plant height was markedly increased with the application of graded doses of NPK and significantly maximum plant height (125.46 $\mathrm{cm}$ ) was observed with the application of 140:40:80 kg NPK ha ${ }^{-1}\left(\mathrm{~T}_{6}\right)$. The combined application of FYM + NPK @ 10 t FYM + 140:40:80 kg NPK ha ${ }^{-1}\left(\mathrm{~T}_{12}\right)$ resulted in significantly maximum plant height $(140.20$ $\mathrm{cm}$ ), which was significantly superior over all other treatments except, $\mathrm{T}_{9}$ (5 t FYM + 140:40:80 kg NPK ha ${ }^{-1}$ ).

\section{Number of tillers}

The data on number of tillers during 2009-10 and 2010-11 as influenced by various treatments of nutrient management are presented in table 1. From the data it was seen that the number of tillers was successively increased with every cutting during the two years of experimentation.

\section{Effect of organic manure (FYM)}

It is evident from the data that, amongst FYM application treatments, the application of 100 $\mathrm{kg} \mathrm{N}$ through FYM $\left(\mathrm{T}_{13}\right)$ to Java citronella 
recorded the significantly higher number of tillers as compared to treatment $\mathrm{T}_{2}$ (FYM @ 5 $\mathrm{t} \mathrm{ha}^{-1}$ ) and $\mathrm{T}_{1}$ (control). However, the treatment $\mathrm{T}_{13}$ was found at par with treatment $\mathrm{T}_{3}$ (FYM @ $10 \mathrm{t} \mathrm{ha}^{-1}$ ) during the first year, whereas, in the second year of crop the treatment $T_{13}$ was statistically significant over all the other FYM treatments (i.e. $\mathrm{T}_{2}$ and $\mathrm{T}_{3}$ ) and control $\left(\mathrm{T}_{1}\right)$. Increased availability of water and nutrients could be responsible for these results.

\section{Effect of NPK fertilizer}

Alone application of NPK graded dose treatment $\mathrm{T}_{6} \quad\left(140: 40: 80 \mathrm{~kg}\right.$ NPK $\left.\mathrm{ha}^{-1}\right)$ recorded the significant highest number of tillers during both the years as compared to other NPK fertilizer doses treatments viz. $\mathrm{T}_{4}$ (80:20:40 kg NPK ha $\left.{ }^{-1}\right)$ and $\mathrm{T}_{5}(100: 30: 60 \mathrm{~kg}$ NPK ha ${ }^{-1}$ ) and $T_{1}$ (control). Formation of plant parts above the soil represent photosynthesis apparatus in conversion of solar energy in to chemical energy totally depends on the utilization of carbohydrates and other metabolites in roots accelerated by nitrogen uptake which ultimately gives more number of tillers. Phosphorus having close relationship in cell division and development, it stimulates early root development and growth. So, it might be the reason to improve tiller number due to increased application of phosphorus. These results were supported by Prakasa Rao et al., (1983), Singh and Singh (1998) and Wankhade et al., (2010).

Further, it is observed that the number of tillers were significantly more with the NPK treatments than FYM alone application. Similar result was reported by Anonymous $\left(1987^{\mathrm{d}}\right)$.

\section{Combined effect}

The data further revealed that, the combined application of FYM with NPK recorded the significantly maximum number of tillers with the treatment $\mathrm{T}_{12}$ (FYM @10 t + NPK@ 140:40:80 kg ha ${ }^{-1}$ ) over rest of the all other combination treatments $\left(\mathrm{T}_{7}\right.$ to $\left.\mathrm{T}_{11}\right)$, NPK fertilizer treatments $\left(\mathrm{T}_{4}, \mathrm{~T}_{5}\right.$ and $\left.\mathrm{T}_{6}\right), \mathrm{FYM}$ treatments $\left(\mathrm{T}_{2}, \mathrm{~T}_{3}\right.$, and $\left.\mathrm{T}_{13}\right)$ and control $\left(\mathrm{T}_{1}\right)$ during both the years of experimentation. This might be due to better and balanced availability of nutrients, resulted in highest uptake of the nutrients by the plant which ultimately resulted in highest number of tillers.

The beneficial effect of FYM along with $\mathrm{N}$, NP and NPK on number of tillers of the plant was earlier reported by many workers (Sharma et al., 1980, Maheshwari et al., 1993, Sukhmal Chand et al., 1996 and Anonymous, 2009).

The pooled analysis data of two years indicated that, among the different FYM treatments, treatment $\mathrm{T}_{13}$ i.e. $100 \mathrm{~kg} \mathrm{~N}$ through FYM recorded significant higher number of tillers (40.46) as compared to other FYM treatments $\left(\mathrm{T}_{2}\right.$ and $\left.\mathrm{T}_{3}\right)$ and $\mathrm{T}_{1}$ (control). Comparatively higher number of tillers (46.64) was recorded with the application of NPK @ 140:40:80 kg ha ${ }^{-1}\left(\mathrm{~T}_{6}\right)$ than other NPK treatments $\left(\mathrm{T}_{4}\right.$ and $\left.\mathrm{T}_{5}\right)$ and $\mathrm{T}_{1}$ (control).

Among the combination treatments, the treatment of FYM @ $10 \mathrm{t}$ along with NPK @ 140:40:80 kg ha ${ }^{-1}\left(\mathrm{~T}_{12}\right)$ recorded the significantly higher number of tillers (58.43) over all the other treatments under study.

\section{Herbage yield}

The data regarding herbage yield of Java citronella as influenced by various treatments of nutrient management are presented in table 2. The data showed that the herbage yield was comparatively higher during the second year of the crop. 


\section{Effect of organic manure (FYM)}

The application of FYM significantly increased the herbage yield as compared to control, further, it is noticed that the herbage yield was found to increase with each addition of FYM dose and significantly highest herbage yield was recorded with the application of $10 \mathrm{t} \mathrm{FYM} \mathrm{ha}^{-1}$ among the FYM treatments. The application of FYM dose equivalent to $100 \mathrm{~kg} \mathrm{~N} \mathrm{ha}{ }^{-1}$ produced comparatively higher herbage yield than application of $10 \mathrm{t} \mathrm{FYM} \mathrm{ha-1}\left(\mathrm{T}_{3}\right)$, however, the significant increase due to the treatment was noticed during second year and pooled means.

The application of higher dose of FYM $\left(\mathrm{T}_{13}\right)$ to the crops which resulted in the better crop growth and ultimately resulted in higher herbage yield. Pareek et al., (1983) revealed that application of FYM @ $10 \mathrm{tha}^{-1}$ showed a beneficial effect on plant height, number of tillers and herbage yield of Palmarosa grown on sandy loam soils. The increase was 42.6 per cent more than no FYM application. The beneficial effect of FYM on physico-chemical and biological properties of the soil resulted in solubilization of nutrients in the soil and thereby increased the availability to the plants, ultimately resulted in increased herbage yield.

\section{Effect of NPK fertilizer}

The application of graded doses of NPK also significantly increased the herbage yield during both the years, further, it is observed that the herbage yield was successively increased with the every increment of graded dose of NPK significantly highest herbage yield was recorded with the application of 140:40:80 kg NPK ha-1 $\left(\mathrm{T}_{6}\right)$ as compared to the treatment $\mathrm{T}_{4}\left(80: 20: 40 \mathrm{~kg} \mathrm{NPK} \mathrm{ha}^{-1}\right)$ and $\mathrm{T}_{5}\left(100: 30: 60 \mathrm{~kg} \mathrm{NPK} \mathrm{ha}{ }^{-1}\right)$. Further, it is noticed that the herbage yield produced due to the application of various graded doses of NPK fertilizer significantly higher herbage yield as compared to the herbage yield produced with the alone application of FYM doses. Due to the application of chemical fertilizers (NPK) the nutrients availability in the soil solution might have increased which resulted in the higher content and uptake of nutrients and ultimately better growth and higher herbage yield.

Several workers have reported the beneficial effect of chemical fertilizers on the herbage yield of Java citronella grown under various soil types and climatic conditions (Dutta and Mishra, 1973, Ghosh and Chatterjee, 1978, Virmani et al., 1979, Singh, 1988 and Nandi and Chatterjee, 1997).

\section{Combined effect}

The data presented in table 2 revealed that the combined application of organic manure (FYM) and chemical fertilizer (NPK) at various doses further enhanced the herbage yield during both the years. The herbage yield was found to increase successively with each combination of FYM doses and graded doses of NPK. Significantly highest herbage yield was produced with the application of $10 \mathrm{t}$ FYM along with 140:40:80 kg NPK ha-1 $\left(\mathrm{T}_{12}\right)$ during both the years under study.

The combined application of organic manure along with chemical fertilizer have favorable effect on the nutrient availability to the crop as well as on the soil properties which might have resulted in better growth and ultimately the higher herbage yield. The results are in agreement with Sharma et al., (1980), Maheshwari et al., (1993), Sukhmal Chand et al., (1996), Anwar et al., (2005), Anonymous (2009), Verma (2010) and Singh et al., (2011). 
Table.1 Plant height and number of tillers of Java citronella as influenced by different treatments of nutrient management

\begin{tabular}{|c|c|c|c|c|c|c|}
\hline \multirow[t]{2}{*}{ Treatments } & \multicolumn{3}{|c|}{ Average Plant height $(\mathrm{cm}) *$} & \multicolumn{3}{|c|}{ Average Number of tillers* } \\
\hline & 2009-10 & 2010-11 & $\begin{array}{c}\text { Pooled } \\
\text { mean }\end{array}$ & 2009-10 & 2010-11 & $\begin{array}{c}\text { Pooled } \\
\text { mean }\end{array}$ \\
\hline $\mathbf{T}_{1}-$ Control & 50.83 & 47.13 & 48.98 & 19.78 & 28.80 & 24.29 \\
\hline \multicolumn{7}{|l|}{ Organic manure doses $\left(\mathrm{t} \mathrm{ha}^{-1}\right)$} \\
\hline $\mathrm{T}_{2}-5 \mathrm{tFYM} \mathrm{ha}^{-1}$ & 63.54 & 70.16 & 66.85 & 26.27 & 35.61 & 30.94 \\
\hline $\mathrm{T}_{3}-10 \mathrm{t}_{\mathrm{FYM} \mathrm{ha}} \mathrm{h}^{-1}$ & 67.19 & 77.82 & 72.50 & 30.71 & 43.16 & 36.93 \\
\hline \multicolumn{7}{|l|}{ NPK fertilizer doses $\left(\mathrm{kg} \mathrm{ha}^{-1}\right)$} \\
\hline $\mathrm{T}_{4}-80: 20: 40 \mathrm{~kg} \mathrm{NPK} \mathrm{ha}^{-1}$ & 102.00 & 110.00 & 106.00 & 34.20 & 45.18 & 39.69 \\
\hline $\mathrm{T}_{5}-100: 30: 60 \mathrm{~kg} \mathrm{NPK} \mathrm{ha}^{-1}$ & 110.56 & 119.02 & 114.79 & 37.02 & 47.57 & 42.29 \\
\hline $\mathrm{T}_{6}-140: 40: 80 \mathrm{~kg} \mathrm{NPK} \mathrm{ha}^{-1}$ & 122.60 & 128.31 & 125.46 & 41.24 & 52.04 & 46.64 \\
\hline \multicolumn{7}{|l|}{ Combined doses (O. M. + NPK fertilizer) } \\
\hline $\mathrm{T}_{7}-5$ t FYM + 80:20:40 $\mathrm{kg} \mathrm{NPK} \mathrm{ha}^{-1}$ & 111.45 & 123.86 & 117.66 & 36.71 & 48.20 & 42.45 \\
\hline $\mathrm{T}_{8}-5$ t FYM + 100:30:60 kg NPK ha $\mathrm{k}^{-1}$ & 118.72 & 130.47 & 124.59 & 39.46 & 50.37 & 44.92 \\
\hline $\mathrm{T}_{9}-5$ t FYM + 140:40:80 kg NPK ha & 131.42 & 137.34 & 134.38 & 45.76 & 57.11 & 51.44 \\
\hline $\mathrm{T}_{10}-10$ t FYM + 80:20:40 $\mathrm{kg} \mathrm{NPK} \mathrm{ha}^{-1}$ & 122.63 & 132.35 & 127.49 & 38.94 & 51.99 & 45.47 \\
\hline $\mathrm{T}_{11}-10$ t FYM + 100:30:60 kg NPK ha ${ }^{-1}$ & 128.05 & 134.26 & 131.15 & 43.17 & 56.12 & 49.64 \\
\hline $\mathrm{T}_{12}-10$ t FYM + 140:40:80 $\mathrm{kg} \mathrm{NPK} \mathrm{ha}^{-1}$ & 140.65 & 139.75 & 140.20 & 51.17 & 65.69 & 58.43 \\
\hline \multicolumn{7}{|l|}{ Organic manure dose equivalent to $100 \mathrm{~kg} \mathrm{~N} \mathrm{ha}^{-1}$} \\
\hline$T_{13}-100 \mathrm{~kg} N$ through FYM (based on FYM analysis) & 73.39 & 82.14 & 77.76 & 33.40 & 47.53 & 40.46 \\
\hline SE $(\mathrm{m}) \pm$ & 3.08 & 3.79 & 2.32 & 0.98 & 1.16 & 0.64 \\
\hline CD at $5 \%$ & 8.98 & 11.05 & 6.77 & 2.85 & 3.39 & 1.87 \\
\hline
\end{tabular}


Table. 2 Herbage yield of Java citronella as influenced by different treatments of nutrient management

\begin{tabular}{|c|c|c|c|}
\hline \multirow[t]{2}{*}{ Treatments } & \multicolumn{3}{|c|}{ Total Herbage yield $\left(\mathrm{t} \mathrm{ha}^{-1}\right)^{*}$} \\
\hline & 2009-10 & 2010-11 & Pooled mean \\
\hline $\mathbf{T}_{1}-$ Control & 5.80 & 5.10 & 5.45 \\
\hline \multicolumn{4}{|l|}{ Organic manure doses $\left(\mathrm{t} \mathrm{ha}^{-1}\right)$} \\
\hline $\mathrm{T}_{2}-5 \mathrm{t} \mathrm{FYM} \mathrm{ha}{ }^{-1}$ & 9.27 & 11.98 & 10.62 \\
\hline$T_{3}-10$ t FYM ha ${ }^{-1}$ & 11.07 & 14.41 & 12.74 \\
\hline \multicolumn{4}{|l|}{ NPK fertilizer doses $\left(\mathrm{kg} \mathrm{ha}^{-1}\right)$} \\
\hline$T_{4}-80: 20: 40 \mathrm{~kg} \mathrm{NPK} \mathrm{ha}^{-1}$ & 16.54 & 17.80 & 17.17 \\
\hline$T_{5}-100: 30: 60 \mathrm{~kg} \mathrm{NPK} \mathrm{ha}^{-1}$ & 17.90 & 18.91 & 18.41 \\
\hline$T_{6}-140: 40: 80 \mathrm{~kg} \mathrm{NPK} \mathrm{ha}^{-1}$ & 19.85 & 19.89 & 19.87 \\
\hline \multicolumn{4}{|l|}{ Combined doses (O. M. + NPK fertilizer) } \\
\hline $\mathrm{T}_{7}-5$ t FYM + 80:20:40 kg NPK ha-1 & 18.84 & 20.70 & 19.77 \\
\hline $\mathrm{T}_{8}-5$ t FYM + 100:30:60 kg NPK ha ${ }^{-1}$ & 20.68 & 21.66 & 21.17 \\
\hline $\mathrm{T}_{9}-5$ t FYM + 140:40:80 $\mathrm{kg} \mathrm{NPK} \mathrm{ha}^{-1}$ & 22.86 & 22.63 & 22.75 \\
\hline$T_{10}-10$ t FYM + 80:20:40 kg NPK ha ${ }^{-1}$ & 21.70 & 24.23 & 22.97 \\
\hline$T_{11}-10$ t FYM + 100:30:60 kg NPK ha ${ }^{-1}$ & 23.74 & 24.86 & 24.30 \\
\hline 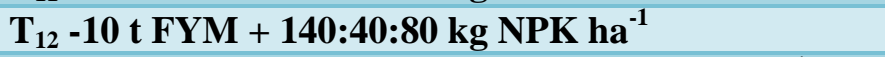 & 25.82 & 27.06 & 26.44 \\
\hline \multicolumn{4}{|l|}{ Organic manure dose equivalent to $100 \mathrm{~kg} \mathrm{~N} \mathrm{ha}^{-1}$} \\
\hline$T_{13}-100 \mathrm{~kg} N$ through FYM (based on FYM analysis) & 12.14 & 16.14 & 14.14 \\
\hline $\mathrm{SE}(\mathbf{m}) \pm$ & 0.61 & 0.50 & 0.36 \\
\hline CD at $5 \%$ & 1.78 & 1.46 & 1.05 \\
\hline
\end{tabular}

* Total herbage yield of three cuttings of each year

The pooled data revealed that among the FYM treatments, the application of FYM equivalent to $100 \mathrm{~kg} \mathrm{~N}\left(\mathrm{~T}_{13}\right)$ produced significantly higher herbage yield by 33.15 and 10.99 per cent than application of $5 \mathrm{t}$ FYM ha ${ }^{-1}\left(\mathrm{~T}_{2}\right)$ and 10 t FYM ha ${ }^{-1}\left(\mathrm{~T}_{3}\right)$, respectively. The application of graded doses of NPK @ 140:40:80 kg NPK ha ${ }^{-1}\left(\mathrm{~T}_{6}\right)$ gave $15.73,7.93,87.10$ and 55.97 per cent higher herbage yield as compared to $\mathrm{T}_{4}(80: 20: 40 \mathrm{~kg}$ NPK ha $\left.{ }^{-1}\right), T_{5}\left(100: 30: 60 \mathrm{~kg} \mathrm{NPK} \mathrm{ha}^{-1}\right), \mathrm{T}_{2}(5$ t FYM ha ${ }^{-1}$ ) and $T_{3}$ (10 t FYM ha ${ }^{-1}$ ), respectively. The application of combined doses of FYM + NPK significantly increased the herbage yield and significantly highest herbage yield was noticed with the application of $10 \mathrm{t} \mathrm{FYM} \mathrm{+} \mathrm{140:40:80} \mathrm{kg} \mathrm{NPK}$ $\mathrm{ha}^{-1}\left(\mathrm{~T}_{12}\right)$ by $86.99,33.06$ and 8.81 per cent over treatments $\mathrm{T}_{13}, \mathrm{~T}_{6}$ and $\mathrm{T}_{11}$, respectively.
From the results, it can be concluded that the conjunctive use of FYM along with chemical fertilizer (10 t FYM + 140:40:80 kg NPK ha ${ }^{1}$ ) was found beneficial way of nutrient management to increase the plant height, number of tillers and herbage yield of Java citronella.

\section{References}

Anonymous. $1987^{\mathrm{d}}$. Nutritional studies in Palmarosa (Bangalore). Annual Report 1986-87. CIMAP, Lucknow (India). pp. 7-8.

Anonymous. 1998. Performance of Palmarosa under bio-fertilizer system (rainfed). AICRP on MAP Biennial Progress Report (1996-97 and 1997-98) of JNKVV, College of Agriculture, Indore, M.P. India. pp. 27-28. 
Anonymous. 2009. Citronella grass-Aromatic plants. Plant Horti. Tech. 8(5):38-39.

Anonymous. 2012. Effect of nutrient management on herbage and oil yield of Jamrosa. Annual report 2011-12. DMAPR, Boriavi (Anand), Gujarat, India. pp. 47-48.

Anwar, M., D.D. Patra, S. Chand, K. Alpesh, A. Nao and S.P.S. Khanuja. 2005. Effect of organic manures and inorganic fertilizer on growth, herb and oil yield, nutrient accumulation and oil quality of French basil. Communications in Soil Sci. and Pl. Analysis. 36(13-14):17371746.

Dutta, P.K. and B.C. Mishra. 1973. Progress Report. Regional Research Laboratory, Bhubaneshwar.

Ghosh, M.L. and S.K. Chatterjee. 1978. Growth and essential oil content of Java citronella in Burdwan, West Bengal, Indian Perfumer. 22:264-268.

Gomez, K.A. and A.A. Gomez. 1984. Statistical procedures for Agricultural Research, John Wiley \& Sons. New York. pp. 241-266.

Maheswari, S.K., R.C. Joshi, S.K. Gangrade, G.S. Chouhan and K.C. Trivedi. 1993. Effect of farm yard manure and zinc on rainfed Palmarosa oil grass. Indian Perfumer. 35(9):226-229.

Nandi, R.P. and S.K. Chatterjee. 1997. Improved cultivation and distillation method followed by Citronella plantation of Darjeeling Hills. Indian Perfumer. 35(1):24-29.

Pareek, S.K., M.L. Maheswari and R. Gupta. $1981^{\mathrm{b}}$. Effect of growth stages, $\mathrm{N}$ and $\mathrm{P}$ fertilizers on herbage and oil yield of Ocimum sanctum L. Report of NBPGR, New Delhi paper presented in $\mathrm{IV}^{\text {th }}$ workshop on MAP $\left(31^{\text {st }}\right.$ Aug to $3^{\text {rd }}$ Sept. 1981) held at TNAU. Madurai. pp. 111.

Pareek, S.K., M.L. Maheshwari and R. Gupta. 1983. Response of Palmarosa oil grass to FYM and micro-nutrients. Report of NBPGR, New Delhi presented in $\mathrm{V}^{\text {th }}$ workshop on MAP ( $4^{\text {th }}-7^{\text {th }}$ Oct. $)$ held at H.P.A.U. Solan. pp. 37-41.

Prakasa Rao, E.V.S., M.R. Narayana, M. Singh and K. Puttanna. 1983. Effect of $\mathrm{N}, \mathrm{P}$ and $\mathrm{K}$ fertilizers on growth, yield and nutrient uptake in Java citronella (Cymbopogon winterianus Jowitt.). Z. Acker. Pflanz. 152:279-283.

Prakasa Rao, E.V.S. and R.S. Ganesha Rao. 1986. Biomass accumulation and nutrient uptake patterns in Java citronella (Cymbopogon winterianus Jowitt.). Indian Perfumer. 30(4):487492.

Sharma, S.N., A. Singh and R.S. Tripathi. 1980. Response of Palmarosa to nitrogen, phosphorus, potassium and Zinc. Ind. J. Agron. 25(4)719-723.

Shiva, M.P., A. Lehri and A. Shiva. 2002. Citronella. Aromatic and Medicinal Plants. Published by International Book Distributors, Dehradun (Uttaranchal), pp.110-116.

Singh, K., 1988. Effect of N, P and K and herbicide applications on production and quality of Java citronella. Ph.D thesis submitted to the BCKVV, Mohanpur, Nadia (West Bengal) India.

Singh K., S. Tripathi and M. Yaseen. 2011. Integrated nutrient management in Indian basil. Annual Report 2010-11. CSIR-CIMAP, Lucknow, India. pp.1.

Singh, M. and C.P. Singh. 1998. Growth and yield response of Lemongrass (Cymbopogon flexuosus) to nitrogen. J. Medi. Arom. Plant Sci. 20(2): 383-385.

Sukhmal Chand and B.K. Rajeswara Rao. 1996. Response of Lemongrass (Cymbopogon flexuosus (Nees exsteud) Wats, var flexuosus Hack) to levels and method of application of phosphorus and potassium. J. Potassium Res. 12(4):400-405.

Sukhmal Chand, P.N. Kaul, A.K. 
Bhattacharya, K. Singh, C.P. Singh and B.R. Rajeswara Rao. 1996. Response of Jamrosa (Cymbopogon spp.) to spacings, FYM, Nitrogen, Phosphorus and Zinc. Indian Perfumer. 40(2):41-46.

Verma, R.K., 2010. Influence of biomass, oil content and oil yield of Geranium under integrated nutrient management systems. Annual Report 2009-10. CIMAP (CSIR), Lucknow, India. pp. 5. Virmani, O.P., K. Singh and R.P. Singh. 1979. Citronella and its cultivation in
India. CIMAP, Lucknow. Farm Bull. No.1. pp.6.

Wankhade, S.G., M. Jaylakshmi, R.B. Sarode, S.V. Gholap and S.B. Nandanwar. 2010. Nutritional management of Palmarosa grown under Inceptisol. Abstract: State level Seminar on "Soil Resource Management for Sustainable Soil Health and Food Security". Akola Chapter on ISSS, Dept. of SSAC, Dr. PDKV, Akola Jan 2-3 ${ }^{\text {rd }}$. pp. 17.

\section{How to cite this article:}

Nandapure, S.P., S.G. Wankhade, S.R. Imade, R.V. Mahajan and Doiphode, G.S. 2020. Growth Parameters and Herbage Yield of Java Citronella as Influenced by Nutrient Management under Inceptisol. Int.J.Curr.Microbiol.App.Sci. 9(05): 1711-1720.

doi: https://doi.org/10.20546/ijcmas.2020.905.192 